\title{
Synthesis and Antibacterial Properties of (-)-nor-Platencin
}

\author{
Olga V. Barykina ${ }^{\dagger}$, Kerri L. Rossi ${ }^{\ddagger}$, Michael J. Rybak ${ }^{\ddagger}$, and Barry B. Snider ${ }^{\star}, \dagger$ \\ tDepartment of Chemistry MS 015, Brandeis University, Waltham, Massachusetts 02454-9110 \\ ¥Anti-Infective Research Laboratory, Eugene Applebaum College of Pharmacy \& Health Sciences, \\ Wayne State University, 259 Mack Avenue, Detroit, Michigan 48201
}

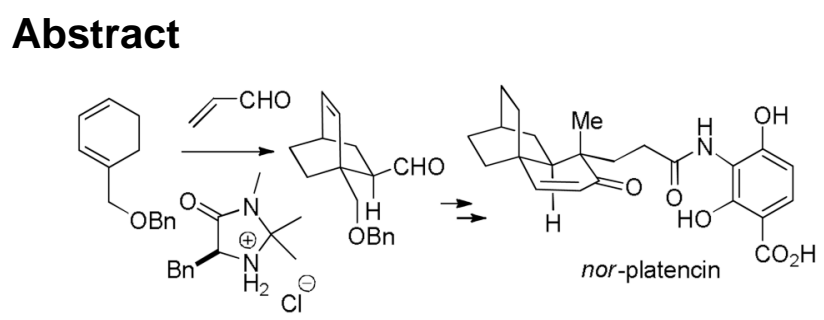

An asymmetric Diels-Alder reaction between acrolein and 1-benzyloxymethyl-1,3-cyclohexadiene affords a bicyclic aldehyde that was elaborated in 11 steps to nor-platencin. nor-Platencin is 4-16 times less active than platencin against several resistant strains of Staphylococcus aureus, macrolideresistant Enterococcus faecalis, and vancomycin-resistant Enterococcus faecium.

Scientists at Merck recently isolated the novel antibiotics platensimycin $(\mathbf{1})^{1,2}$ and platencin $(2)^{3}$ (see Figure 1). These compounds are the first potent inhibitors of bacterial fatty acid biosynthesis (Fab), which is needed for the survival of bacterial pathogens. This pathway is highly conserved among bacteria and is distinct from the mammalian pathway. Platensimycin blocks the fatty acid condensing enzyme $\beta$-ketoacyl-[acyl carrier protein] synthase II (FabF) selectively, whereas platencin inhibits both enzymes FabF and $\beta$-ketoacyl-[acyl carrier protein] synthase III (FabH) with $\mathrm{IC}_{50}$ values of 1.95 and $3.91 \mu \mathrm{g} / \mathrm{mL}$ in Staphylococcus aureus. These antibiotics do not exhibit cross-resistance to key antibiotic resistant strains, including methicillin-resistant $S$. aureus, vancomycin-intermediate $S$. aureus and vancomycin-resistant Enterococcus faecium. Platencin shows potent in vivo efficacy without any observed toxicity.

As expected from the novel structures and potent antibacterial activity, both platensimycin (1) ${ }^{4,5}$ and platencin $(2)^{6}$ have been the object of intense synthetic interest. Numerous analogues of platensimycin have also been prepared, establishing that the aromatic moiety is crucial for activity, but that there is some room for structural modification of the tricyclic diterpenoid moiety. ${ }^{7}$ No close analogues of platencin have been prepared. We speculated that the exomethylene group of platencin is not needed for biological activity, but is simply present because it is a structural feature of the terpenoid precursor. The exo-methylene group is acid sensitive and may also decrease the metabolic stability of platencin. Finally, the methylene group complicates the synthesis by introducing both reactive functionality and an additional chiral center at the carbon marked by an asterisk. Our goal therefore was to develop a short synthesis of nor-platencin (3) which lacks the exo-methylene group of platencin (2).

snider@brandeis.edu.

Supporting Information Available: Complete experimental procedures, copies of ${ }^{1} \mathrm{H}$ and ${ }^{13} \mathrm{C}$ NMR spectral data. This material is available free of charge via the Internet at http://pubs.acs.org. 
Our retrosynthesis is outlined in Scheme 1. We planned to prepare nor-platencin (3) from enone 4, $\mathrm{R}=\mathrm{H}$ or Me, using methods developed for the synthesis of platencin (2). Enone $\mathbf{4}$ will be prepared by an intramolecular aldol reaction of keto aldehyde $5, \mathrm{R}=\mathrm{H}$ or Me, which can be prepared by homologation of Diels-Alder adduct $\mathbf{6}$, which will be synthesized from the readily available 1,3-cyclohexadienemethanol $(\mathbf{7 a}, \mathrm{R}=\mathrm{H})^{8}$ and acrolein $(\mathbf{8 a}, \mathrm{R}=\mathrm{H})$ or methyl vinyl ketone $(\mathbf{8 b}, \mathrm{R}=\mathrm{Me})$. Use of methyl vinyl ketone would introduce the methyl group early in the synthesis. Use of acrolein would require methylation of $\mathbf{4 a}$, as in the platencin syntheses. 7

The Diels-Alder reaction of $\mathbf{7 a}, \mathrm{R}^{1}=\mathrm{H}$, with methyl vinyl ketone $(\mathbf{8 b})$ proceeded poorly either thermally or with Lewis acid catalysis, but gave a reasonable yield of racemic Diels-Alder adduct $6 \mathbf{6}$ and stereo- and regioisomers by reaction "on water". ${ }^{9}$ Unfortunately, the Diels-Alder adducts were difficult to work with because they exist as a mixture of open and hemiketal tautomers. We were able to prepare $6 \mathbf{b}, \mathrm{R}^{1}=\mathrm{TBS}$ and $\mathrm{R}^{2}=\mathrm{Me}$, but all attempts to homologate this by a Wittig reaction resulted in enolization of the hindered methyl ketone. For these reasons we turned to acrolein (8a) as the dienophile and readily available 1,3-cyclohexadienylmethyl benzyl ether (7b $)^{10}$ as the diene. The protecting group will prevent formation of hemiacetals and will be removed without an additional step during hydrogenation of the double bond. Enolization should not occur during homologation of $\mathbf{6 c}$ because the carbonyl group is an aldehyde rather than a methyl ketone.

In the reaction of $\mathbf{7 b}$ with acrolein $(\mathbf{8 a})$ as the dienophile, we were able to take advantage of MacMillan's asymmetric Diels-Alder reaction using $10 \%$ of imidazolone $\mathbf{9}^{11}$ as the catalyst in 19:1 $\mathrm{CH}_{3} \mathrm{CN} / \mathrm{H}_{2} \mathrm{O}$ for 5 days (see Scheme 2). This afforded a 9:1 mixture of the desired endo adduct $\mathbf{6 c}$ and exo adduct 10, from which $\mathbf{6 c}(32 \%)$ and $\mathbf{1 0}(4 \%)$ were isolated in pure form along with an additional $10 \%$ of impure $\mathbf{6 c}$. Other conditions, including $\mathrm{MeOH} / \mathrm{H}_{2} \mathrm{O}$ and $\mathrm{CH}_{3} \mathrm{NO}_{2} / \mathrm{H}_{2} \mathrm{O}$, were less successful. Chiral HPLC established that the ee of the major product 6c is $87 \%$. Our yield does not compare favorably with that reported by MacMillan for the reaction of 1,3-cyclohexadiene with $\mathbf{8 a}$ catalyzed by $5 \%$ of $\mathbf{9}$ which gave a 14:1 mixture of endo and exo isomers in $82 \%$ yield with $94 \%$ ee for the endo isomer. ${ }^{11 a}$ However, in his synthesis of hapalaindole Q, Kerr carefully optimized the Diels-Alder reaction of 1,3dimethyl-1,3-cyclohexadiene with 3-(3-( $N$-tosyl)in-dolyl)acrolein catalyzed by $40 \%$ of 9 to obtain a maximum yield of $35 \%$ with $85: 15$ endo/exo selectivity and $93 \%$ ee for the endo isomer. ${ }^{11 \mathrm{c}}$ As Kerr also noted in his synthesis, ${ }^{11 \mathrm{c}}$ the rapid and enantioselective assembly of the key intermediate $\mathbf{6 c}$ makes this route attractive despite the modest yield.

The lower ee in our case could result from an uncatalyzed background reaction. Reaction of $7 \mathbf{b}$ and $8 \mathbf{a}$ for 5 days without catalyst 9 afforded Diels-Alder adducts in $10 \%$ yield. The background reaction will be much less significant in the presence of catalyst 9 because the diene is consumed in the more rapid catalyzed reaction. The ee can probably be improved somewhat by increasing the catalyst loading. Equilibration of both $\mathbf{6 c}$ and $\mathbf{1 0}$ with aqueous $\mathrm{NaOH}$ in EtOH afforded the identical 3:1 mixture of $\mathbf{6 c}$ and 10. The catalyst controls the stereochemistry adjacent to the aldehyde center so that epimerization of exo adduct $\mathbf{1 0}$ will give ent-6c, providing another possible explanation for the lower ee. However, the isolation of a 9:1 mixture of endo isomer $\mathbf{6} \mathbf{c}$ and exo isomer $\mathbf{1 0}$ suggests that epimerization is not a major issue.

Homologation of $\mathbf{6 c}$ by a Horner-Wittig reaction ${ }^{12}$ now proceeded smoothly to give $\mathbf{1 1}$ as a 3:2 mixture of stereoisomers in 67\% yield (see Scheme 3). Hydrolysis of $\mathbf{1 1}$ in a two phase system ${ }^{13}$ with aqueous $\mathrm{HCl}$ in $\mathrm{CH}_{2} \mathrm{Cl}_{2}$ and THF provided the homologated aldehyde $\mathbf{1 2}$ in $90 \%$ yield. Addition of MeMgBr to 12 afforded secondary alcohol $\mathbf{1 3}$ in $99 \%$ yield as a mixture of stereoisomers. Buffered PCC oxidation of $\mathbf{1 3}$ gave ketone $\mathbf{1 4}$ in $>90 \%$ yield. To our surprise, hydrogenation of $\mathbf{1 4}$ afforded mainly tetrahydropyran $\mathbf{1 5}$. Hydrogenation and hydrogenolysis 
provided the desired saturated hydroxy ketone which cyclized to form the hemiketal. Further reduction, probably by dehydration to the enol ether and hydrogenation, afforded $\mathbf{1 5}$.

We therefore decided to carry out the hydrogenation and hydrogenolysis before formation of the ketone. Hydrogenation of $\mathbf{1 3}$ afforded a mixture of 1,5-diols $\mathbf{1 6}$ in $77 \%$ yield. Swern oxidation appears to be the method of choice for the oxidation of 1,5-diols to keto aldehydes, ${ }^{14}$ because other procedures give the $\delta$-lactone as a byproduct. ${ }^{15}$ Swern oxidation of $\mathbf{1 6}$ using $i$ - $\mathrm{Pr}_{2} \mathrm{EtN},{ }^{16}$ rather than $\mathrm{Et}_{3} \mathrm{~N}$, gave the unstable keto aldehyde $\mathbf{5 a}$, which was treated with $\mathrm{NaOH}$ in EtOH to give the desired cyclohexenone $\mathbf{4 a}^{17}$ in $70 \%$ overall yield from $\mathbf{1 6}$.

Alkylation of 4a with LHMDS and MeI in 10:1 THF/HMPA afforded 87\% of $\mathbf{4 b}$ containing a few percent of the stereoisomer (see Scheme 4). ${ }^{6 b}$ Elaboration of $\mathbf{4 b}$ to carboxylic acid $\mathbf{1 8}$ was carried out using procedures developed by Corey for the preparation of a platensimycin analogue and by Mulzer for the synthesis of platencin. ${ }^{6 \mathrm{~h}, 7 \mathrm{~b}}$ Treatment of $\mathbf{4 b}$ with $t$-BuOK and methyl acrylate in ether $/ t-\mathrm{BuOH}$ for 30 minutes at $0{ }^{\circ} \mathrm{C}$ provided a 5:1 mixture of ester $\mathbf{1 7}$ and the diastereomer from which the desired isomer $\mathbf{1 7}$ was isolated in $39 \%$ yield by preparative HPLC. Hydrolysis of $\mathbf{1 7}$ afforded acid $\mathbf{1 8}$ in $71 \%$ yield. Amide formation was accomplished by reaction of acid $\mathbf{1 8}$ with protected aniline $19^{5 \mathrm{~d}, 6 \mathrm{6}, 18}$ using HATU $(O$-(7-azabenzotriazol-1yl)- $N, N, N^{\prime}, N^{\prime}$-tetramethyluronium hexafluorophosphate) in DMF for $38 \mathrm{~h}$ to give trimethylsilylethyl ester 20 (58\%), which was hydrolyzed with TASF in DMF to provide (-) nor-platencin (3) in $56 \%$ yield.

The antibiotic acitivity of nor-platencin (3) was deter-mined against several resistant strains of Staphylococcus aureus, macrolide-resistant Enterococcus faecalis, and vancomycinresistant Enterococcus faecium. The minimum inhibitory concentration (MIC) data shown in Table 1 indicate that nor-platencin (3) is 4-16 times less potent than platencin (2) as an antibiotic. As with platencin (2), the best activity is shown against vancomycin-resistant Enterococcus faecium. The reduced potency of $\mathbf{3}$ indicates that the exo methylene group of platencin (2) contributes modestly to the antibiotic activity.

In conclusion, an asymmetric Diels-Alder reaction between acrolein (8a) and 1benzyloxymethyl-1,3-cyclohexadiene (7b) affords bicyclic aldehyde $\mathbf{6 c}$ that was elaborated in 11 steps to nor-platencin (3). nor-Platencin (3) is 4-16 times less potent than platencin (2) against several bacterial strains indicating that the exo methylene group of platencin (2) contributes modestly to the antibiotic activity.

\section{Supplementary Material}

Refer to Web version on PubMed Central for supplementary material.

\section{Acknowledgments}

We are grateful to the National Institutes of Health (GM-50151) for support of this work.

\section{References}

1. (a) Wang J, Soisson SM, Young K, Shoop W, Kodali S, Galgoci A, Painter R, Parthasarathy G, Tang YS, Cummings R, Ha S, Dorso K, Motyl M, Jayasuriya H, Ondeyka J, Herath K, Zhang C, Hernandez L, Allocco J, Basilio Á, Tormo JR, Genilloud O, Vicente F, Pelaez F, Colwell L, Lee SH, Michael B, Felcetto T, Gill C, Silver LL, Hermes JD, Bartizal K, Barrett J, Schmatz D, Becker JW, Cully D, Singh SB. Nature 2006;441:358-361. [PubMed: 16710421] (b) Singh SB, Jayasuriya H, Ondeyka JG, Herath KB, Zhang C, Zink DL, Tsou NN, Ball RG, Basilio A, Genilloud O, Diez MT, Vicente F, Pelaez F, Young K, Wang J. J. Am. Chem. Soc 2006;128:11916-11920. [PubMed: 16953632]

Org Lett. Author manuscript; available in PMC 2010 November 19. 
2. For a review, see: Manallack DT, Crosby IT, Khakham Y, Capuano B. Curr. Med. Chem 2008;15:705710. [PubMed: 18336284]

3. (a) Wang J, Kodali S, Lee SH, Galgoci A, Painter R, Dorso K, Racine F, Motyl M, Hernandez L, Tinney E, Colletti SL, Herath K, Cummings R, Salazar O, Gonzalez I, Basilio A, Vicente F, Genilloud O, Pelaez F, Jayasuriya H, Young K, Cully DF, Singh SB. Proc. Nat. Acad. Sci 2007;104:7612-7616. [PubMed: 17456595] (b) Jayasuriya H, Herath KB, Zhang C, Zink DL, Basilio A, Genilloud O, Diez MT, Vicente F, Gonzalez I, Salazar O, Pelaez F, Cummings R, Ha S, Wang J, Singh SB. Angew. Chem., Int. Ed 2007;46:4684-4688.

4. For a review of early syntheses of platensimycin, see: Tiefenbacher K, Mulzer J. Angew. Chem., Int. Ed 2008;47:2548-2555.

5. For more recent syntheses of platensimycin, see: (a) Nicolaou KC, Pappo D, Tsang KY, Gibe R, Chen DY-K. Angew. Chem., Int. Ed 2008;47:944-946. (b) Kim CH, Jang KP, Choi SY, Chung YK, Lee E. Angew. Chem., Int. Ed 2008;47:4009-4011. (c) Matsuo J, Takeuchi K, Ishibashi H. Org. Lett 2008;10:4049-4052. [PubMed: 18702494] (d) Ghosh AK, Xi K. J. Org. Chem 2009;74:1163-1170. [PubMed: 19123842] (e) Yun SY, Zheng J-C, Lee D. J. Am. Chem. Soc 2009;131:8413-8415. [PubMed: 19473019]

6. For syntheses and formal syntheses of platencin, see: (a) Nicolaou KC, Tria GS, Edmonds DJ. Angew. Chem., Int. Ed 2008;47:1780-1783. (b) Hayashida J, Rawal VH. Angew. Chem., Int. Ed 2008;47:4373-4376. (c) Tiefenbacher K, Mulzer J. Angew. Chem., Int. Ed 2008;47:6199-6200. (d) Yun SY, Zheng J-C, Lee D. Angew. Chem., Int. Ed 2008;47:6201-6203. (e) Nicolaou KC, Toh Q-Y, Chen DY-K. J. Am. Chem. Soc 2008;130:11292-11293. [PubMed: 18665593] (f) Waalboer DCJ, Schaapman MC, van Delft FL, Rutjes FPJT. Angew. Chem., Int. Ed 2008;47:6576-6578. (g) Austin KAB, Banwell MG, Willis AC. Org. Lett 2008;10:4465-4468. [PubMed: 18798641] (h) Tiefenbacher K, Mulzer J. J. Org. Chem 2009;74:2937-2941. [PubMed: 19260660] (i) Varseev GN, Maier ME. Angew. Chem., Int. Ed 2009;48:3685-3688. (j) Ghosh AK, Xi K. Angew. Chem., Int. Ed 2009;48:5372-5375.

7. For syntheses of platensimycin analogues, see: (a) Nicolaou KC, Stepan AF, Lister T, Li A, Montero A, Tria GS, Turner CI, Tang Y, Wang J, Denton RM, Edmonds DJ. J. Am. Chem. Soc 2008;130:1311013119. [PubMed: 18771264] (b) Yeung Y-Y, Corey EJ. Org. Lett 2008;10:3877-3878. [PubMed: 18665602] (c) Wang J, Lee V, Sintim HO. Chem. - Eur. J 2009;15:2747-2750. (d) Shen HC, Ding FX, Singh SB, Parthasarathy G, Soisson SM, Ha SN, Chen X, Kodali S, Wang J, Dorso K, Tata JR, Hammond ML, MacCoss M, Colletti SL. Bioorg. Med. Chem. Lett 2009;19:1623-1627. [PubMed: 19233644] (e) Jang KP, Kim CH, Na SW, Kim H, Kang H, Lee E. Bioorg. Med. Chem. Lett 2009;19:4601-4602. [PubMed: 19604693]

8. (a) Botica I, Mirrington RN. Aus. J. Chem 1971;24:1467-1480.see also (b) Hickson CL, McNab H. J. Chem. Soc., Perkin Trans. 1 1988:339-342. (c) Hunig S, Kahanek H. Chem. Ber 1957;90:238-245.

9. Chanda A, Fokin VV. Chem. Rev 2009;109:725-748. [PubMed: 19209944]

10. Harding KE, Strickland JB, Pommerville J. J. Org. Chem 1988;53:4877-4883.

11. (a) Ahrendt KA, Borths CJ, MacMillan DWC. J. Am. Chem. Soc 2000;122:4243-4244. (b) Northrup AB, MacMillan DWC. J. Am. Chem. Soc 2002;124:2458-2460. [PubMed: 11890793] (c) Kinsman AC, Kerr MA. J. Am. Chem. Soc 2003;125:14120-14125. [PubMed: 14611249] (d) Wilson RM, Jen WS, Macmillan DWC. J. Am. Chem. Soc 2005;127:11616-11617. [PubMed: 16104734] (e) MacMillan DWC, Lelais G. Aldrichimica Acta 2006;39:79-87. (f) Gordillo R, Houk KN. J. Am. Chem. Soc 2006;128:3543-3553. [PubMed: 16536527]

12. Earnshaw C, Wallis CJ, Warren S. J. Chem. Soc., Perkin Trans. 1 1979;12:3099-3106.

13. Stork G, Niu D, Fujimoto A, Koft ER, Balkovec JM, Tata JR, Dake GR. J. Am. Chem. Soc 2001;123:3239-3242. [PubMed: 11457058]

14. (a) Chênevert R, Courchesne G, Caron D. Tetrahedron: Asymmetry 2003;14:2567-2571. (b) Maddess ML, Tackett MN, Watanabe H, Brennan PE, Spilling CD, Scott JS, Osborn DP, Ley SV. Angew. Chem., Int. Ed 2007;46:591-597. (c) Mukaiyama T, Pudhom K, Yamane K, Arai H. Bull. Chem. Soc. Jpn 2003;76:413-425. (d) Karche NP, Pierry C, Poulain F, Oulyadi EL, Pannecoucke X, Quirion JC. Synlett 2007:123-126.

15. See, for instance: Hansen TM, Florence GJ, Lugo-Mas P, Chen J, Abrams JN, Forsyth CJ. Tetrahedron Lett 2003;44:57-59.

Org Lett. Author manuscript; available in PMC 2010 November 19. 
16. Rose NGW, Blaskovich MA, Evindar G, Wilkinson S, Luo Y, Fishlock D, Reid C, Lajoie GA. Org. Syn 2002;79:216-227. Much lower yields of 5a were obtained using $\mathrm{Et}_{3} \mathrm{~N}$.

17. The synthesis of $\mathbf{4 a}$ by an asymmetric intramolecular Robinson annulation was recently reported: $\mathrm{Li}$ P, Yamamoto H. Chem. Commun 2009:5412-5414.

18. Heretsch P, Giannis A. Synthesis 2007:2614-2616. 


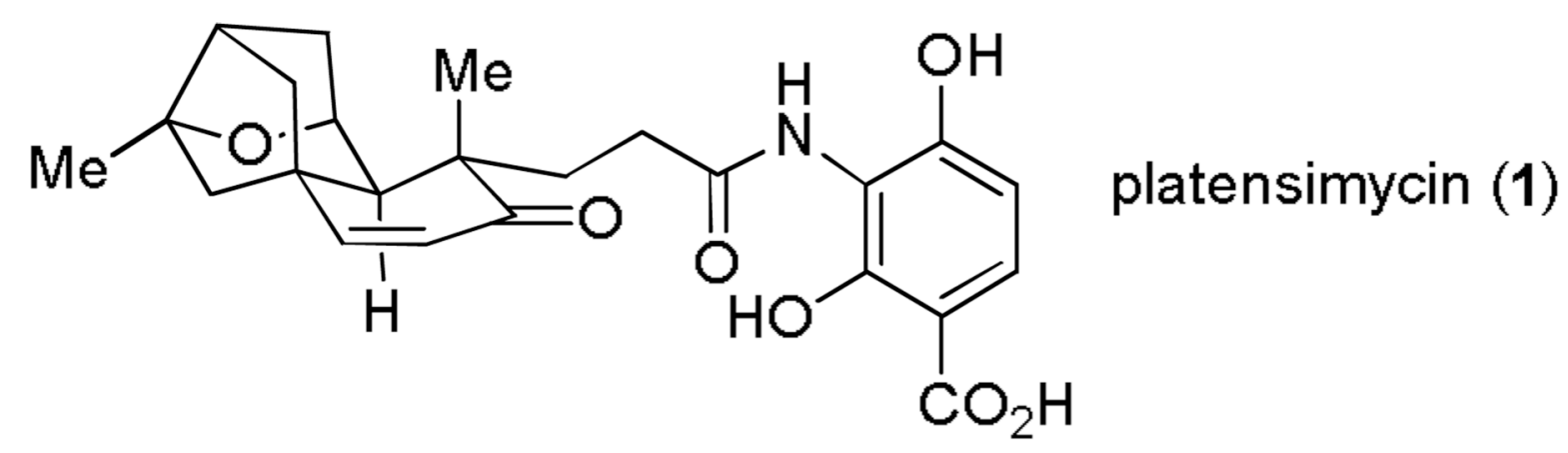<smiles>[Y]C1C[C@]2(C)C=CC(=O)C([Y4])(CCC(=O)Nc3c(O)ccc(C(=O)O)c3O)C1CC2</smiles>

platencin, $\mathrm{X}=\mathrm{CH}_{2}(2)$ nor-platencin, $\mathrm{X}=\mathrm{H}_{2}$ (3)

Figure 1.

Structures of platensimycin (1), platencin (2), and nor-platencin (3). 
<smiles>CCC1(C)C(=O)C=C2C=CC3CCC2C31</smiles>

nor-platencin (3)<smiles>Cc1ccc(O)c(NC(=O)O)c1O</smiles>

$\mathrm{CO}_{2} \mathrm{H}$

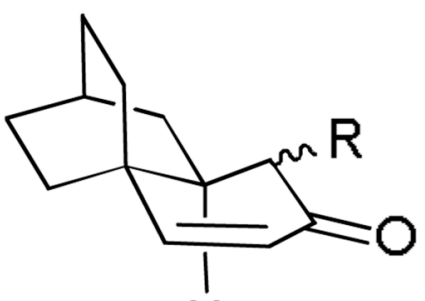

$\mathrm{H}$

4a, $\mathrm{R}=\mathrm{H}$<smiles>[R]OCC1=CC=CCC1</smiles><smiles>C=C</smiles>

7a, $\mathrm{R}^{1}=\mathrm{H} \quad 8 \mathrm{a}, \mathrm{R}^{2}=\mathrm{H}$

$7 b, R^{1}=B n \quad 8 b, R^{2}=M e$<smiles>[R7]C[C@]1(C([R2])=O)CC2C=C[C@H]1CC2</smiles><smiles>[R]C(C(C)=O)C1CC2CCC1(C)CC2</smiles>
$\mathrm{OR}^{1}$

Scheme 1.

Retrosynthesis of nor-Platencin (3)

6a, $R^{1}=H, R^{2}=M e$ 6b, $R^{1}=T B S, R^{2}=M e$ $6 c, R^{1}=B n, R^{2}=H$ 5a, $\mathrm{R}=\mathrm{H}$

$5 b, R=M e$ 
<smiles>C1=CCCC(COc2ccccc2)=C1</smiles>

$7 \mathrm{~b}$
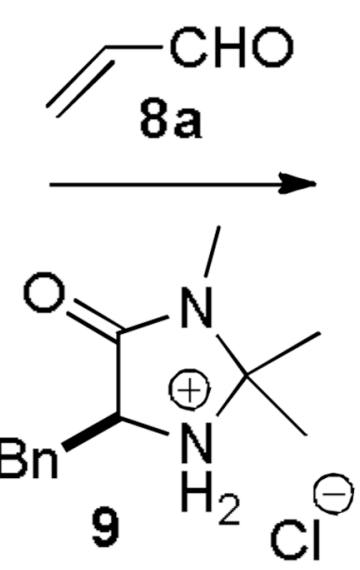

$19: 1 \mathrm{CH}_{3} \mathrm{CN} / \mathrm{H}_{2} \mathrm{O}$ $5 \mathrm{~d}, 23^{\circ} \mathrm{C}$
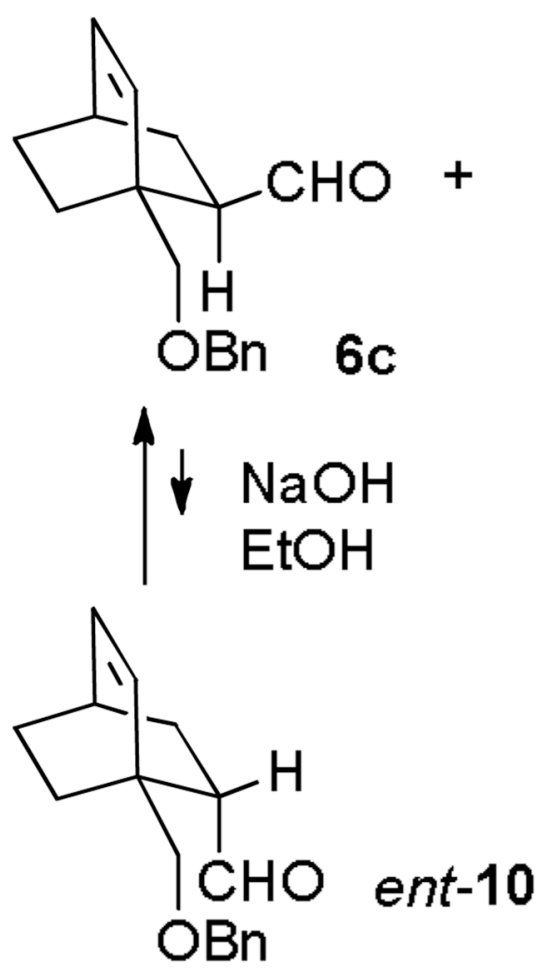

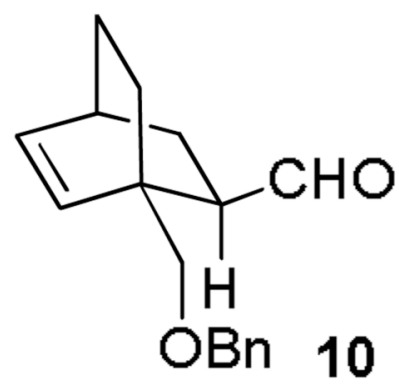

$\uparrow \mid \begin{aligned} & \mathrm{NaOH} \\ & \mathrm{EtOH}\end{aligned}$

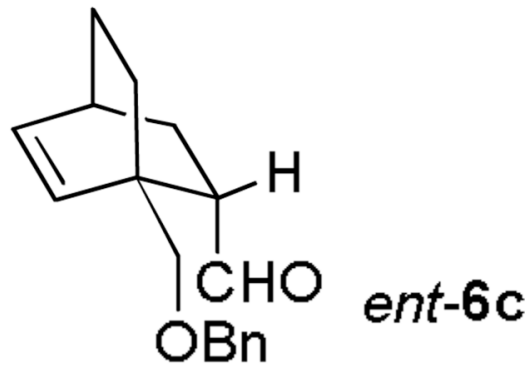

Scheme 2.

Diels-Alder Reaction of $\mathbf{7 b}$ and $\mathbf{8 a}$ 
$\mathrm{Ph}_{2} \mathrm{P}(\mathrm{O}) \mathrm{CH}_{2} \mathrm{OMe}$

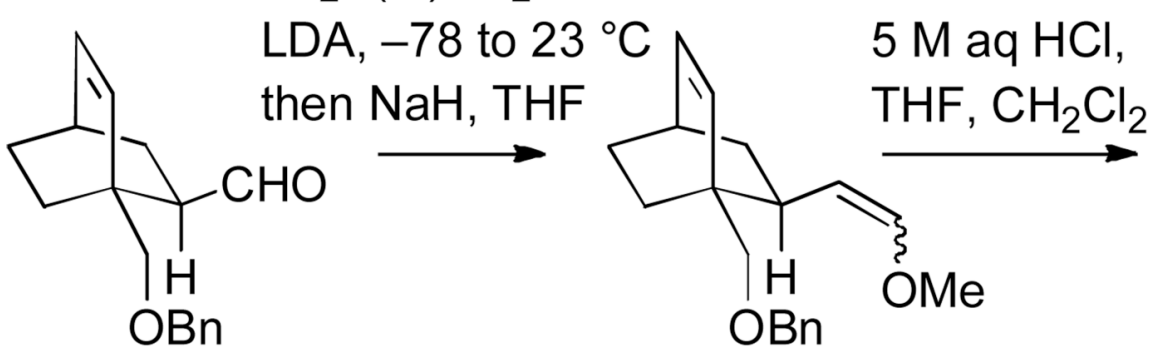

6c

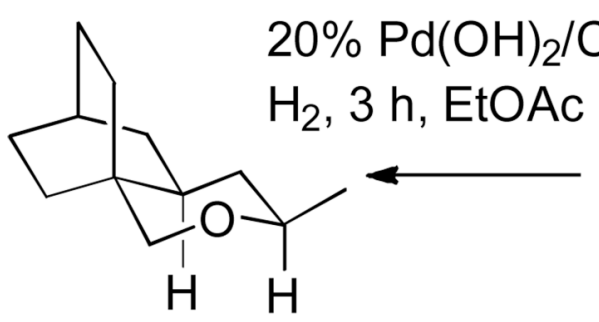

$15(\sim 60 \%)$
$11(67 \%, 3: 2 E / Z)$

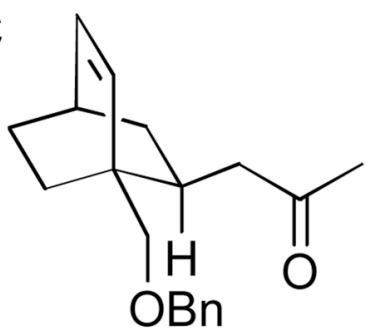

$14(>90 \%)$

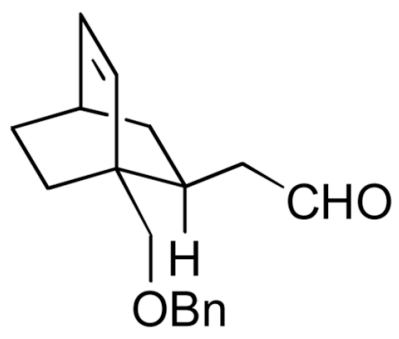

$12(90 \%)$

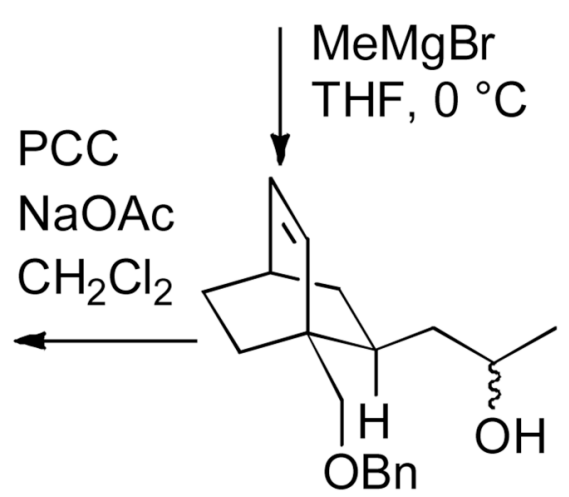

$13(99 \%)$

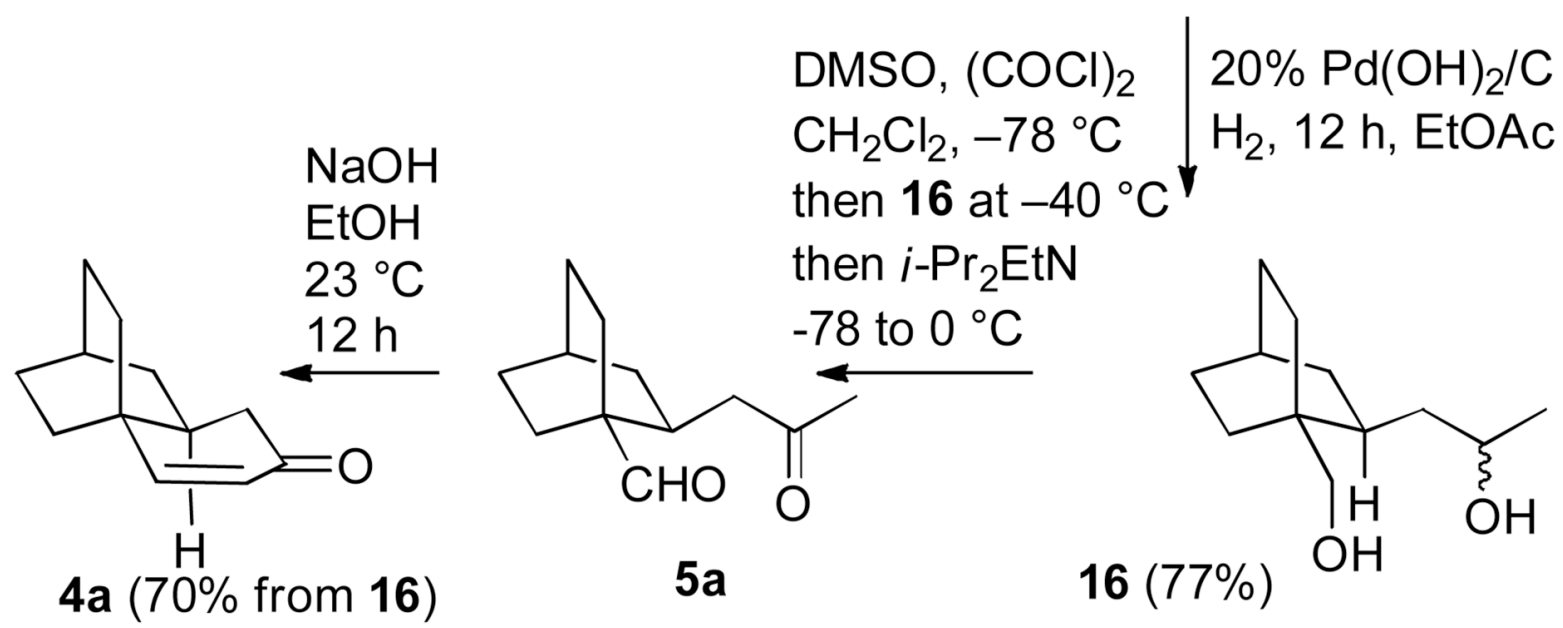

Scheme 3.

Synthesis of Tricyclic Enone $\mathbf{4 a}$ 

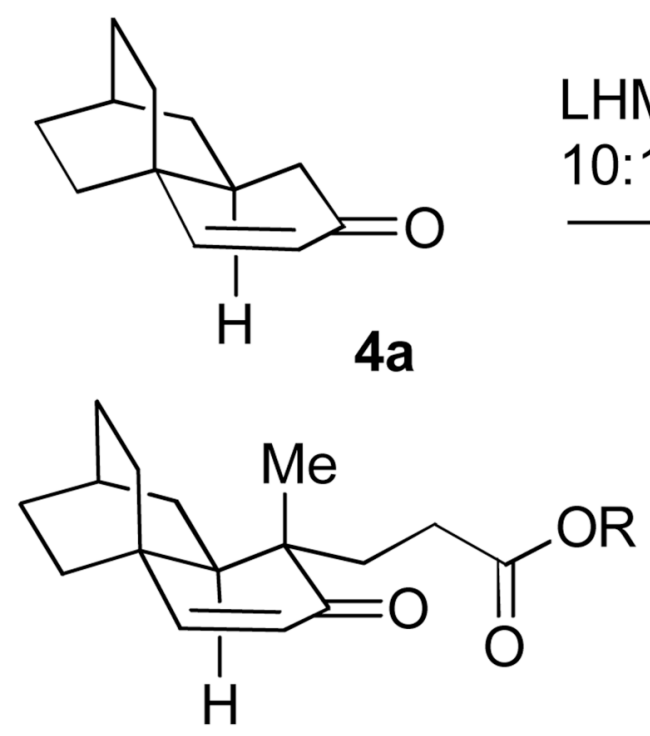

LHMDS, Mel 10:1 THF/HMPA
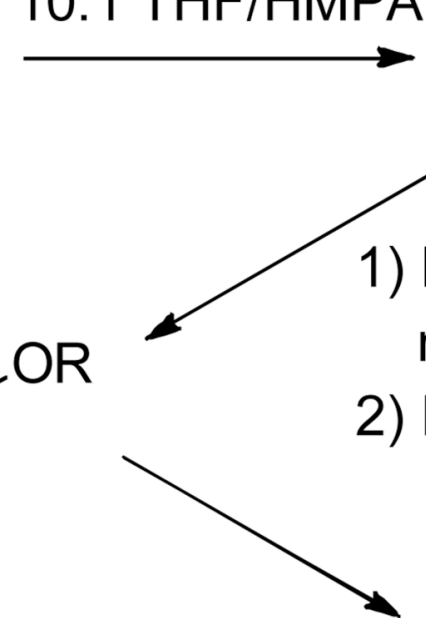

1) $\mathrm{KOt}-\mathrm{Bu}, t-\mathrm{BuOH} / \mathrm{Et}_{2} \mathrm{O}$ methyl acrylate

2) $\mathrm{NaOH}, \mathrm{THF}, \mathrm{H}_{2} \mathrm{O}$

17, $\mathrm{R}=\mathrm{Me}(39 \%)$

18, $\mathrm{R}=\mathrm{H}(71 \%)$

1) 19, $\mathrm{HATU}, \mathrm{Et}_{3} \mathrm{~N}$ DMF, $38 \mathrm{~h}$<smiles>C[As](C)([Na])(=S)CCOC(=O)c1ccc(O)c(N)c1O</smiles><smiles>[R]OC(=O)c1ccc(O)c(NC(=O)CCC2(C)C(=O)C=C3C4CCC(CC4)C32)c1O</smiles>

20, $\mathrm{R}=\mathrm{CH}_{2} \mathrm{CH}_{2} \mathrm{TMS}(58 \%)$ 3, $\mathrm{R}=\mathrm{H}$ (nor-platencin, 56\%)

Scheme 4.

Completion of the nor-Platencin (3) Synthesis 
Table 1

Antibiotic Activity of Platencin (2) and nor-Platencin (3)

\begin{tabular}{|c|c|c|}
\hline organism and genotype & platencin (2) MIC $\mu \mathrm{g} / \mathrm{mL}^{a}$ & nor-platencin (3) MIC $\mu \mathrm{g} / \mathrm{mL}^{b}$ \\
\hline $\begin{array}{l}\text { S. aureus (MSSA) } \\
\text { S. aureus (MRSA) } \\
\text { S. aureus (MRSA) plus serum } \\
\text { S. aureus (MRSA macrolide-R and Linezolid-R) } \\
\text { S. aureus (VISA) } \\
\text { S. aureus (VRSA) } \\
\text { S. aureus (hVISA) } \\
\text { S. aureus (MRSA daptomycin-R) } \\
\text { E. faecalis (macrolide-R) } \\
\text { E. faecium (vancomycin-R) } \\
\text { E. coli }\end{array}$ & $\begin{array}{l}0.5 \\
1 \\
8 \\
1 \\
0.5 \\
1 \\
\text { ND } \\
\text { ND } \\
2 \\
<0.06 \\
>64\end{array}$ & $\begin{array}{l}4 \\
4 \\
>32 \\
4 \\
8 \\
16 \\
4 \\
4 \\
16 \\
0.25 \\
>32\end{array}$ \\
\hline
\end{tabular}

${ }^{a}$ Data from reference $3 \mathrm{a}$.

${ }^{b}$ MIC determined according to: Methods for Dilution Antimicrobial Susceptibility Tests for Bacteria That Grow Aerobically; Approved Standard -Eighth Edition.

Document M07-A8; Clinical and Laboratory Standards Institute: Wayne, Pennsylvania, 2008. ND = not determined. R = resistant 